\title{
ОСОБЛИВОСТІ ПОДАТКОВОЇ ПЕРЕВІРКИ ЯК ФОРМИ ПОДАТКОВОГО КОНТРОЛЮ
}

Анотація. У статті розглянуто категорію «податкова перевірка» та науково обгрунтовано теоретичні і нормативні положення проведення перевірок податковими органами. Проведено комплексне та всебічне дослідження правових норм, що регулюють порядок застосування компетентними державними органами форм і методів податкового контролю з урахуванням сучасних тенденцій розвитку податкового контролю в Україні. Проаналізовано низку законів і підзаконних актів, що регулюють питання проведення планових і позапланових документальних перевірок, фрактичних, камеральних, виїзних, зустрічних, цільових, повторних перевірок. Проведене дослідження особливостей податкових перевірок дозволило констатувати багатогранність і багатоаспектність проблеми в понятійному апараті і в нормативному регулюванні.

Ключові слова: перевірка, контроль, інформація, податкові органи, облік, звітність.

Prots Ivanna, Lepish Nataliya Lviv State University of Internal Affairs

\section{FEATURES OF TAX AUDIT AS A FORM OF TAX CONTROL}

Summary. The article considers the category of "tax audit" and scientifically substantiates the theoretical provisions of inspections by tax authorities. A comprehensive and comprehensive study of the legal norms governing the application by the competent state authorities of forms and methods of tax control, taking into account current trends in the development of tax control in Ukraine. It is substantiated that the legal regime of tax audits requires additional legal regulation by supplementing the Tax Code of Ukraine with missing legal norms. A number of laws and bylaws regulating the issues of scheduled and unscheduled documentary inspections, actual, in-house, on-site, counter, targeted, re-inspections are analyzed. As a result of the study it was found that the tax audit is a single form of tax control regulated by regulations on taxes and fees, consisting of a set of audit measures conducted by the tax authority, using methods of tax control of correctness, completeness and timeliness of payment (transfer ) taxes and fees, initiated by the tax authority or the taxpayer with the possibility of further appeal of its results in the prescribed manner. One of the determining criteria for the development and investment attractiveness of the business environment is the clarity of regulatory and supervisory policy, ie the implementation of control measures (inspections) by authorized government agencies. Tax audits are one of the most effective measures taken by the tax authorities against dishonest taxpayers, related to bringing to justice those who violated tax laws. Any tax audit combines features that can be considered grounds for classification and, accordingly, inclusion in different types of tax audits. It is concluded that the subjects of tax audit are tax returns and accounting documents, which, in accordance with the legislation on taxes and fees, must be issued in accordance with the requirements established for the relevant type of documents. The study of the peculiarities of tax audits allowed us to state the versatility of the problem in the conceptual framework and in regulation.

Keywords: inspection, control, information, tax authorities, accounting, reporting.

$\Pi$ остановка проблеми. Податкові перевірки є одними 3 найбільш ефективних заходів, що проводяться податковими органами щодо несумлінних платників податків, пов'язані з притягненням до відповідальності осіб, які порушили податкове законодавство. Перевірка - це спосіб здійснення контролю контролюючими органами правильності нарахування, своєчасності та повноти сплати податків і зборів, а також дотримання законодавства 3 питань проведення розрахункових та касових операцій, патентування, ліцензування та іншого законодавства, контроль за дотримання якого покладено на контролюючі органи. Законодавець встановив, що органи державної податкової служби мають право проводити камеральні, документальні (планові або позапланові; виїзні або невиїзні) та фрактичні перевірки. Слід зазначити, що нормативна диференціація податкових перевірок значною мірою впливає на загальну теоретичну модель податкового контролю. Класифікувати податкові перевірки за видами слід з урахуванням усієї сукупності принципових особливостей їх організації та проведення. Будь-яка податкова перевірка поєднує в собі риси, які можна вважати підставами для класифрікації та, відповідно, включення до різних видів податкових перевірок.

Аналіз останніх досліджень і публікацій. Розвиток і вдосконалення законодавства про податки і збори зумовило необхідність теоретичних досліджень, в тому числі в частині податкового контролю і податкових перевірок. Зазначеною проблематикою займалися, зокрема, дослідники фрінансового права: Д.В. Вінницький, Г.А. Гаджієв, В.І. Гурєев, Р.Ф. Захарова, А.Н. Козирін, I.I. Кучеров, Н.П. Кучерявенко, М.Ю. Орлов, С.Г. Пепеляєв, Г.В. Петрова, Г.П. Толстопятенко, Д.С. Щокін та ін.

Істотний внесок у вироблення наукових уявлень про механізм правового регулювання податкових перевірок і перспективи його вдосконалення внесли такі вчені, як: O.I. Баїк, А.С. Титов, Н.П. Бортник, І.Б. Тацишин, Л.К. Воронова, О.А. Соколова, О.П. Орлюк, Л.А. Савченко та ін.

Метою статті $є$ вироблення та обгрунтування теоретичних і практичних положень, спрямованих на вдосконалення правового аналізу здійснення податкових перевірок в Україні. 
Виклад основного матеріалу. Контролюючі органи мають право проводити податкові перевірки в порядку, встановленому законодавством України.

Відповідно до ст. 75 ПК України, контролюючі органи проводять такі види податкових перевірок:

1) камеральні перевірки;

2) документальні ( планові або позапланові; виїзні або невиїзні) перевірки;

3) фактичні перевірки [1].

Термін «камеральна податкова перевірка» використовувався в законодавстві і до прийняття ПК. Виходячи з концептуального положення про те, що зовнішнім проявом сутності поняття «податковий контроль» $е$ податкова перевірка, представляеться можливим зробити висновок, що камеральна податкова перевірка - це вид податкової перевірки, що складаеться 3 комплексу заходів з дослідження податкових декларацій і документів, поданих платником податків, службовців підставою для обчислення і сплати податку, а також інших документів про діяльність платника податків, наявних у податкового органу, що проводиться посадовими особами податкового органу, відповідно до їх службовими обов'язками без будь-якого спеціального рішення керівника податкового органу за місцем знаходження податкового органу, регламентованих нормативними правовими актами про податки і збори і має на меті перевірку правильності i повноти сплати податків і зборів до відповідних бюджетів, а також дотримання інших норм законодавства про податки і збори Камеральна перевірка проводиться посадовими особами контролюючого органу без будь-якого спещіального рішення керівника (його заступника або уповноваженої особи) такого органу або направлення на її проведення.

Термін «виїзна податкова перевірка» раніше ПК ніде не використовувався. Податкове законодавство користувалося поняттям «Документальна податкова перевірка». Фахівці висловлюють думку, що поняття "виїзна» і «документальна» податкові перевірки - це синоніми. Так, виїзна податкова перевірка - це перевірка, яка проводиться, як правило, в приміщенні платника податків. Документальна перевірка - це перевірка первинної бухгалтерської документації та облікових регістрів платника податків. При цьому жоден нормативно-правовий акт не уточнюе місце проведення такої перевірки.

Виїзна податкова перевірка - це вид податкової перевірки, що складається з комплексу заходів, що проводяться податковим органом на підставі рішення керівника (його заступника) податкового органу за місцем фактичного місцезнаходження платника податків (платника зборів, податкового агента), регламентованих нормативними правовими актами про податки i збори і має на меті перевірку правильності і повноти сплати податків та зборів до відповідних бюджетів, а також дотримання інших норм законодавства про податки і збори.

Основними учасниками податкових перевірок є об'єкт аудиту або індивідуальні підприемці i податковий орган (його посадові особи). Однак, в ході проведення виїзної податкової перевірки, за ініціативою податкового органу можуть бути залучені й інші особи, наприклад, експерти та перекладачі $[2$, с. 86$]$.

Залежно від місця проведення податкової перевірки і від обсягу документацію, що перевіряе, податкові перевірки поділяються на:

- камеральні;

- виїзні;

За обсягом перевірених питань, податкові перевірки поділяються на:

- комплексні;

- тематичні;

- цільові;

За способом організації податкові перевірки поділяються на:

- планові;

- позапланові;

ПК передбачає також можливість проведення:

- контрольних;

- повторних перевірок;

За обсягом перевіряються документів перевірки діляться на:

- суцільні;

- вибіркові [3, с. 223].

В рамках камеральної та виїзної податкових перевірок, на практиці раніше широко застосовувався і такий вид перевірки, як зустрічні . Наприклад, якщо при проведенні камеральних і виїзних податкових перевірок у податкових органів виникае необхідність одержання інформації про діяльність платника податків (платника збору), пов'язаної з іншими особами, податковим органом можуть бути витребувані у цих осіб документи, що відносяться до діяльності платника податків (платника збору).

Проводяться також комплексні, тематичні та цільові податкові перевірки.

Комплексна перевірка - це перевірка фінансової та господарської діяльності організації за певний період часу з усіх питань дотримання податкового законодавства. В даний час частота проведення комплексних перевірок не встановлена. При наявності у податкового органу підстав припускати, що облік і сплата податків (зборів) ведуться 3 порушеннями законодавства про податки і збори, комплексні перевірки можуть проводитися не рідше одного разу на три роки. Необхідно відзначити, що платники податків, які мають позитивну репутащію, можуть не піддаватися комплексним перевіркам.

Практично всі податкові перевірки здійснюються у вигляді комплексних. До ціеї категорії можна включити і такі питання, як правильність обчислення і перерахування податків (зборів) платником податків, виконання функщій податкового агента; правильність списання з рахунків платників податків сум податків і санкцій; відкриття рахунків платникам податків (при перевірці банків); застосування контрольно-касової техніки; порядку реалізації алкогольної продукції та ін. Тільки виїзна податкова перевірка дозволяе використовувати весь спектр прав, наданих податковим органам.

Тематична перевірка - це перевірка окремих питань фінансової і господарської діяльності організації (наприклад, перевірка правильності обчислення і сплати податку на прибуток, ПДВ, податку на майно та інших податків). Такі перевірки проводяться в міру необхідності, яка визначається керівником податкового органу. 
Цільова перевірка - це перевірка дотримання податкового законодавства за певним напрямом або фінансово господарськими операціями організації. Такі перевірки проводяться з питань взаеморозрахунків з постачальниками і покупцями продукції (послуг), за експортно-імпортними операціями, за певною угодою, по розміщенню тимчасово вільних грошових коштів, правильності застосування пільг і щодо будь-яких інших фінансово-господарських операцій. Результати цільової перевірки використовуються при комплексній або тематичної перевірки та оформляються або в актах цих перевірок, або як окремі додатки. Можливе проведення цільових перевірок і як самостійних. Однак в цьому випадку виникае небезпека неповної перевірки окремих питань дотримання податкового законодавства [4, с. 30].

Податкові перевірки можуть бути плановими і позаплановими. Планова перевірка - превірка з попереднім повідомленням платника податків. Позапланова перевірка - це різновид виїзної податкової перевірки, проведеної без попереднього повідомлення платника податків (на відміну від планової перевірки).

Комплексні та вибіркові податкові перевірки проводяться в залежності від обсягу документацію, що перевіряе. Комплексні перевірки проводяться, коли проводиться перевірка всіх документів організації, без пропусків і припущень про відсутність порушень. Вибіркові перевірки проводяться, коли перевіряеться тільки частина документації.

Існуе чимало доктринальних визначень податкових перевірок. Так, Спіріна Л.В. вважає, що податкова перевірка - сукупність спеціальних прийомів податкового контролю, що застосовуються уповноваженими органами 3 метою встановлення достовірності і законності відображення об'єктів оподаткування та порядку сплати податків і зборів в бухгалтерській звітності та інших носіях індормації [5, с. 40].

На думку М.А. Дудника, податкова перевірка - процесуальна дія податкового органу 3 контролю за правильністю обчислення, своечасністю і повнотою сплати (перерахування) податків (зборів). Вона здійснюеться шляхом зіставлення фактичних даних, отриманих в результаті податкового контролю, з даними податкових декларацій, поданих до податкових органів.

Об'єктом податкової перевірки $є$ правильність і повнота сплати податків і зборів, а також дотримання норм законодавства про податки і збори. Предметом податкової перевірки е документи, які мають відношення до обчислення і сплати податків та на які спрямована діяльність податкових органів при проведенні ними податкових перевірок. Предметом податкової перевірки можуть бути будь-які документи, що знаходяться в розпорядженні платника податків і які стосуються його діяльності, а також предмети, приміщення та території, 3 використанням яких пов'язана діяльність платника податків [6, с. 88].

Найбільш значущими предметами податкової перевірки є податкові декларації і документи бухгалтерського обліку, які, відповідно до законодавства про податки і збори, повинні бути оформлені відповідно до вимог, що встановлюються для відповідного виду документів.
Податкові перевірки - найважливіша і невід'ємна частина практичної діяльності податкових органів країни.

У літературі зазначаеться, що суб'єктами податкових перевірок є органи, яким відповідно до податкового законодавства надано повноваження $з$ проведення заходів податкового контролю щодо контрольованих організацій i фрізичних осіб. Даний підхід видається дискусійним. Якщо визначити поняття “суб'єкт» як особа, що володіе правами і обов'язками, то будь-які особи, які беруть участь в проведенні податкової перевірки, є суб'єктами правовідносин, що виникають в процесі здійснення податкового контролю [7, с. 93].

При проведенні податкових перевірок перетинаються інтереси держави і інтереси платників податків. У таких правовідносинах владним суб'єктом є держава в особі податкових органів. Законодавство в подібних випадках має гарантувати дотримання інтересів найменш захищених суб'єктів податкових правовідносин (в нашому випадку - платників податків) шляхом більш чіткої регламентації процесуальної поведінки контролюючого суб'єкта.

Необхідно відзначити, що при розгляді процесуальних аспектів проведення податкових перевірок, виникають питання про те, наскільки правомірно включати податкову перевірку в провадження у справах про податкові правопорушення?

Дійсно, податкові правопорушення, як правило, виявляються при здійсненні податкового контролю та, зокрема, шляхом проведення податкових перевірок. Однак беззастережне включення податкової перевірки в провадження у справах про податкові правопорушення $е$ не зовсім вірним i, зокрема, не відповідае встановленій ПК презумпції невинності платника податків. Кожен платник податків вважаеться невинним у вчиненні податкового правопорушення, доки його вину не буде доведено у встановленому законом порядку. При цьому податкова перевірка може і не виявити податкових правопорушень. Зокрема, можна вивести три варіанти результатів податкової перевірки:

a) при проведенні податкової перевірки не виявлено податкових правопорушень;

б) при проведенні податкової перевірки виявлені податкові правопорушення, які, згодом, не підтверджені рішенням суду за позовом платника податків;

в) при проведенні податкової перевірки виявлені податкові правопорушення, які або визнані самим платником податків, або їх наявність підтверджено рішенням суду [7, с. 94].

Таким чином, з розглянутих варіантів тільки останній, може претендувати на місце в провадженні у справах про податкові правопорушення [8, с. 48]. На підставі вищевикладеного знову виникае питання про доцільність включення податкової перевірки, що закінчилася виявленням реальних податкових правопорушень, 3 урахуванням презумпції невинуватості платника податків, в провадження у справах про податкові правопорушення на стадії підготовки до ії проведення, або на стадії ï проведення, тобто до моменту оформлення результатів перевірки? На думку більшості, немае. В іншому випадку можна говорити про презумпцію винності платника податків, що суперечить ПК [9, с. 119]. 
Висновки і пропозиції. Таким чином проведення податкової перевірки не завжди приводить до розгляду справ про податкові правопорушення, але при цьому, жодне провадження у справах про податкові правопорушення неможливо без стадії виявлення даних правопорушень, які виявляються за допомогою податкового контролю. Виходячи з цього, можна зробити висновок про те, що стадія виявлення податкового право- порушення - це необхідна стадія провадження у справах про податкові правопорушення. Таким чином, вченими пропонуються різні варіанти визначень податкової перевірки. Однак всі вони в тій чи іншій мірі відображають суть податкової перевірки, як такої. Тому, слід виходити з того, що податкова перевірка - це, перш за все, форма податкового контролю, що має бути відображено в понятті про неї.

\section{Список літератури:}

1. Податковий кодекс України від 02.12.2010. URL: https://zakon.rada.gov.ua/laws/show/2755-17\#n1768

2. Гусак Н.Е., Гусак Ю.Д. Контроль податкових органів за діяльністю підприемств : Навчальний посібник. Київ : Центр учбової літератури, 2007. 320 с.

3. Іванов Ю.Б., Крисоватий А.І., Десятник О.М. Податкова система : Підручник. Київ : Атіка, 2006.920 с.

4. Дудник М.А. Податкові перевірки як одна з основних форм податкового контролю. Фінансовий контроль. 2004. № 2. C. 32-41.

5. Рубан Н.І. Впроваджуемо нову форму контролю. Фінансовий контроль. 2003. № 3(16). С. 40-42.

6. Щетинін А.І. Гроші та кредит : Підручник. Вид. 2-ге, перероб. та доп. Київ : ЦНЛ, 2006. 432 с.

7. Бандурка О.О. Управління державною податковою службою в Україні : монографія. Харків, 2005. 504 с.

8. Назар Ю.С., Проць I.М. Адміністративна та фінансово-правова відповідальність за порушення бюджетного законодавства : монографія. Львів : Львівський державний університет внутрішніх справ, 2018. 172 с.

9. Ковалів М.В., Єсімов С.С., Проць І.М., Лозинський Ю.Р. Правове регулювання фінансового контролю в Україні : навч. посіб. Львів : ЛДУВС, 2018. 267 с.

\section{References:}

1. Podatkovyy kodeks Ukrayiny vid 02.12.2010. URL: https://zakon.rada.gov.ua/laws/show/2755-17\#n1768

2. Husak N.E., Husak Yu.D. (2007) Kontrol' podatkovykh orhaniv za diyal'nistyu pidpryyemstv [Control of tax authorities over the activities of enterprises]: Navchal'nyy posibnyk. Kyiv: Tsentr uchbovoyi literatury, $320 \mathrm{p}$.

3. Ivanov Yu.B., Krysovatyy A.I., Desyatnyk O.M. (2006) Podatkova systema [The tax system]: Textbook. Kyiv: Atika, $920 \mathrm{p}$.

4. Dudnik M.A. (2004) Podatkovi perevirky yak odna z osnovnykh form podatkovoho kontrolyu [Tax audits as one of the main forms of tax control]. Finansovyy kontrol', no. 2, pp. 32-41.

5. Ruban N.I. (2003) Vprovadzhuyemo novu formu kontrolyu. [We are introducing a new form of control]. Finansovyy kontrol', no. $3(16)$, pp. 40-42.

6. Shchetynin A.I. (2006) Hroshi ta kredyt [Money and credit]: Pidruchnyk: vyd. 2-he, pererob.ta dop. Kyiv: TSNL, 432 p.

7. Bandurka O.O. (2005) Upravlinnya derzhavnoyu podatkovoyu sluzhboyu v Ukrayini [Management of the State Tax Service in Ukraine]: monohrafiya. Kharkiv, 504 p.

8. Nazar Yu.S., Prots I.M. (2018) Administratyvna ta finansovo-pravova vidpovidal'nist' za porushennya byudzhetnoho zakonodavstva [Administrative and financial-legal responsibility for violation of budget legislation]: monohrafiya. L'viv: L'vivs'kyy derzhavnyy universytet vnutrishnikh sprav, $172 \mathrm{p}$.

9. Kovaliv M.V., Yesimov S.S., Prots' I.M., Lozyns'kyy Yu.R. (2018) Pravove rehulyuvannya finansovoho kontrolyu v Ukrayini [Legal regulation of financial control in Ukraine]: navch. posib. L'viv: LDUVS, $267 \mathrm{p}$. 